\title{
Politics of Staging Capitalist Society in Transcultural Adaptations of Brecht's the Threepenny Opera by Ajoka Theatre in Pakistan
}

Taimur Kayani*, Arbaayah Ali Termizi, Wan Roselezam Wan Yahya, Ida Baizura Bahar

Faculty of Modern Languages and Communication, Universiti Putra Malaysia, 43400, Serdang, Selangor, Malaysia

Corresponding Author: Taimur Kayani, E-mail: taimurkayani2011@hotmail.com

\section{ARTICLE INFO}

Article history

Received: November 04, 2017

Accepted: January 13, 2018

Published: May 01, 2017

Volume: 7 Issue: 3

Advance access: March 2018

Conflicts of interest: None

Funding: None

\begin{abstract}
Brecht's canonical literary work's indigenization in Pakistan can offer a valuable transcultural adaptation study because it was performed through a radical theatre with a distinct dramaturgy and political philosophy in two different cultural contexts and historical frame of references. As the foremost representative of Brecht's radical dramaturgy, philosophy and literary works in Pakistan since 1983, Ajoka theatre utilized these adaptations as a platform for airing a critique on capitalism in Pakistan. Prior researches focused on the formal criticism: visual and aural elements. No contextual reading is conducted to explore its political and cultural dimensions of these transcultural adaptations in providing descriptive critique on capitalist society of Pakistan. Realizing the paucity of indigenous academic work in this area this article takes this initiative and addresses this 'research gap' by first conducting a new historicist study of Brecht selected work and its transcultural adaptations in Pakistan. This article also investigates the theatrical and cultural factors which contributed to the enormous success of these transcultural adaptations of Brecht's selected work in Pakistan in light of Hutcheon's theory of adaptation.
\end{abstract}

Key words: Transcultural Adaptation, Ajoka Theatre, Representations of Capitalist Society, Hutcheon's Theory of Adaptation, New Historicism

\section{INTRODUCTION}

Historically, since 1980s Pakistani society was sharply transformed by the pro-capitalist policies of Zia-ul-Haq and later on his protégé' Nawaz Sharif extended his economic policies under the banner of Islamic capitalism. Ajoka adapted Brecht's work, The The Threepenny Opera, in two bold political productions at two critical historic junctions in a highly significant way. Both adaptations are actually a satirical representations of emerging powerful and violent Pakistani pro-Islamic capitalist society in early 1990s during Sharif first period and post 9/11 period of Musharraf respectively. Hutcheon (2006) in her theory of adaptation views adaptation as a source to "engage in a larger social or cultural critique" (94). Highly critical and interestingly, both plays were initially banned by the successive state authorities after their huge successful reception. Later on, Ajoka got court orders for their enactments.

Khalid (2011) in his article, "The Folk Elements in Ajoka's Work" points out the 'new' characteristics of Pakistani society due to distortion of history, emergence of techno-capitalism mired in corruption and politics based on reductionism:

Today one witnesses a society based on intolerance, hatred, chauvinistic nationalism, ignorance and denial. It has resulted in making villains out of traditional loving Pakistani.
This articlealso investigates the "ideological motivation" behind the descriptive critique on capitalist society in these adaptations. It also reveals the theatrical and cultural factors which contributed to the enormous success of these transcultural adaptations.

According to Hans (2014), new historicists assert the role of literature as a political practice, rather than view literature as developing form within its own autonomous history (20). Even before the advent of new historicism in 1980s, in Western criticism, investigation into the potentiality of literary works in propagation of political philosophy 'to subvert the status quo' had been a highly fruitful tradition.

Stephen Ingles (1979) in his ground breaking study, Socialist Thoughts in imaginative literature cited several examples in this direction; The Novel and Revolution (Alan Swingewood 1975), Writers and Politics in Modern Britain (J.A. Morris, 1977), Politics and Literature in Modern Britain (George Watson 1977). This research investigates the contribution of literary writers to the propagation of political thought (1). The American critic Stephen Orgel in his book, Illusions of Power: Political Theatre in the English Renaissance (1975) takes one step further and declares that drama is a social and discursive practice which takes active role as a practical component in a field of discourses invested with power (57). However, unfortunately, this 'Genre' has

Published by Australian International Academic Centre PTY.LTD.

Copyright (c) the author(s). This is an open access article under CC BY license (https://creativecommons.org/licenses/by/4.0/) http://dx.doi.org/10.7575/aiac.ijalel.v.7n.3p.23 
not been developed and investigated in any depth in Pakistan in particular and in South Asia in general (Rehman 2014). Transcultural adaptations of Brecht's selected work in Pakistan can provide the research 'opportunity' to evaluate the productive effect of adaptations in forwarding a particular social and political philosophy in different cultural and historical framework.

This articleis significant for three reasons. Firstly, it investigates an intense conflict between two economic systems i.e. Capitalism and Socialism in German society in 1920s and Pakistani society in 1990s in two significant phases in the light of new historicism to gain enhanced understanding and appreciation of The Threepenny Opera (1928) and its transcultural adaptations in Pakistan. These socio-economic conflicts had enormous effects on the German and Pakistani society. In first phase by "historicizing literature" it analyzes the various events and movements in Nazi Germany (193345) and Zia's Pakistan (1977-88) to arrive at better understanding of Brecht's capitalist society in The Threepenny Opera (1928) and its localize adaptations Takay da Tamasha (1991) and Burqa Vaganza (2007). In second and equally important phase, which can be referred as "textualizing history" this articleexamines the transcultural adaptions of Brecht's selected work to comprehend the society and culture within which it was produced and received. The new historicism approach aims to clarify the issues that made Brecht's work and its transcultural adaptations important for its first audiences.

Thirdly, in the context of adaptation studies, this research article also renders theoretical contribution to Hutcheon's theory of adaptation by engaging with the "historically conditioned reasons" that necessitated these adaptations. Hutcheon states:

Yet in literary studies, this dimension of response [Reasons behind adaptation] has been sidelined. However, adapters deeply personal as well as culturally and historically conditioned reasons should be considered seriously by adaptation theory, even if this means rethinking the role of intentionality in our critical thinking about art in general" (95)

This article is organized as follows. The first part explores the "collaborative nature" of The Threepenny Opera through the lens of new historicism and frames it in a socio-political and historical dimension of its time. The second part explores the 'cultural politics' behind the transcultural adaptation, TDA and examines how re-contextualizing it in a different cultural setting and historical framework gives a 'new political meaning' and a 'new creative life' to the Brecht selected source text and the final part shows the after effects of the addition of religious dimension to the second transcultural adaptation, Burqavaganza, in Ajoka theatre. Burqavaganza is about an existing fierce interplay between capitalism and family relations to represent 'love' in the rising Islamic capitalist society in Pakistan.

Pritner \& Walters (2005) in their book, Introduction to play analysis consider that social systems in which the characters live affect them enormously and play's social and religious setting is highly significant in understanding the conflict it presents. At the very outset the study utilizes their definition of society to discuss its contours in The Threepenny Opera and its transcultural adaptations:

The term social and society refer to the way people live in relationship to each other. Clearly politics, economics and religion interact to create much of what is thought of as a society or a societal system. (24)

Historically speaking by staging emerging "bourgeoisie capitalist society" on $31^{\text {st }}$ August, 1928 in Berlin, young and ambitious thirty year old Brecht anxiously wanted to bring a socialist insight into how human relations were effected or determined by economic, social and political forces 'fiercely' controlled by the capitalist ideology during his times (Raza 1999).

The Threepenny Opera is selected out of numerous Brecht's work because this work was his first descriptive and comical critique of capitalist society on stage. It was a 'political comedy', with bawdy cabaret style songs which served as provocative social statements by combining high culture with low. Sulieman's work, Studies in Modern Drama: Brecht (2011), is a helpful starting point in locating the historical implication of Brecht's work particularly in his discussion of capitalism. He substantiates and sums up the 'prevailing view' on The Threepenny Opera as "creative output" of genius Brecht mind that "can transcend history". It is appropriate to observe his point of view:

Ideologically, The Threepenny Opera grew out of its young author's experiences in Berlin during the Weimar Republic (1919-33), when Germany struggled to establish a parliamentary democracy in the face of economic devastation, notorious decadence, and bitter military defeat. More than ten million German were without any source of income, and crime proliferated as citizens were reduced to begging on the street. Horrified by the poverty and mounting violence, Brecht took The Beggar's Opera by eighteenth-century English satirist John Gay and re-imagined it through the lens of his dramatic theories. (9)

However, re-examination of socio-political environment surrounding the selected text through new historicism lens points out some valuable contradictory features. Sulieman's approach to Brecht's work presents a partial truth. For instance, The Threepenny Opera was not a product of 'single consciousness' but out of 'collaborative efforts' of many individuals or forces. For instance, John Fuegi (1994) in "The Zelda syndrome: Brecht and Elisabeth Hauptmann" pinpoints the imperative role in conceiving dramatic work as Brecht himself confessed in his "own dairies" about his inability to work alone. He states:

Reading the diaries of the late teenager and young adult Brecht one sees that he was uncomfortable working alone on anything except short poems and regularly took things from published sources as well as taking things from friends in his closest circle, most particularly Caspar Neher, Ludwig Prestel and George Pfanzelt. As an 18 year-old he compares himself to two successful German playwrights, boasting: I can write, I can write plays better than Hebbel and wilder than Wedekind' but he 
also notes: 'I am lazy. I'm unable to become famous (104)

Therefore, it is pertinent to note that there were many collaborators besides the social and political forces behind the creative 'invention' and unprecedented success of The Threepenny Opera in 1928. Evan (1970) also presents the influential impact that another outstanding director, Picastor had on Brecht's work. He asserts:

It was in 1930s that Brecht, basing his ideas on Piscator's theories, began to develop his own Form of epic theatre. Piscator was right when he said the epic theatre was invented by me primarily in production and by Brecht primarily in the script'. Whereas Brecht went back to story line, Piscator returned to the documents. (67)

These above mentioned cited statements justify the new historicism assumption in which literary works are not products of a single vision but of many social and cultural forces at certain historical points therefore, it is pertinent to explore their contextual perspective. Due to significance of these works in certain historical and geographical framework it can be argued that they cannot be universal and timeless as suggested by the previous researches on Brecht's literary works. At the article's center is the premise that due to historic and geographic specifications of Brecht's selected text, transcultural adaptation by performing re-contextualization seems the appropriate literary engine that can drive the play into the next century, new geographical location and in new language.

Historically speaking, The Threepenny Opera is an extension of the vision of John Gay's $18^{\text {th }}$ century Beggar's Opera. Brecht's The Threepenny Opera (1928) like its source play text is a scathing satire on bourgeois society of its period. By re-contextualizing and bringing theatrical innovations to $18^{\text {th }}$ century text, Brecht re-creates a new descriptive critique of capitalist society in $20^{\text {th }}$ century. He constructs play's representative characters as clowns and challenges the prevailing social order of Weimar Republic.

The hero-villain of the play is Mac the knife who is sharp, ruthless and reckless (Unlike Gay's dashing romantic hero) but at the same time representative of bourgeois values and business ethics. The world of soho is populated by gangsters, policemen, priests, beggar-operators, who set the scene of wheeling-dealing, corruption, betrayals and farcical but it is a scathing attack on the hypocritical values and cut throat competition in a capitalist society.

It can be argued that by placing the selected text in a new historicism frame work as suggested by new historicism one can also critically review it as a 'sociological document' on the society of Weimar republic era. By focusing on the Wiemar republic it indicates and answers the reasons why Germany voted for Nazism which actively supported the capitalist ideals? As Welch says "What went wrong and when did it go wrong" (Welch 1993). This play provides an 'another vision of history' of Weimar Republic. Brecht indicates that capitalist set of values has penetrated in German bourgeoisie society due to interactive link between capitalism and criminality. This connection is highlighted through the dialogues of his characters. Later on one observes that same interactive connection between capitalism and criminality gave rise to Hitler. It is pertinent to note that in 1928 Hitler was a struggling politician and was seeking intimate relationship with the business world (Welch 1993).

Love is the binding force which unites and carries forward a society seems to be a 'cliché statement' in Brecht's perspective in the selected play text. He asserts that this over used bourgeoisie statement is false and contradictory in nature and practice. Actually business transcends love in a capitalist society therefore, love is a mere financial transaction for this class.

Importantly, all characters follow this love 'intrinsic relationship' with money to justify the 'naturalness' of this new emerging model of love. Polly, a character positively painted by the previous researches and critics (Sulieman 2011,Rogers 2013). I argue even in initial passionate argument Polly intentionally and smartly places financial consideration to convince her parents. She knows that money is a central concern of her parents however; she misses a point that it is the image of power that brings money in fierce business competition in the social structure she lives. Therefore, all characters speak the language of capitalism by using business vocabulary. Out of fun love is portrayed ironically. Normally parents would be convinced by arguments of Love, but Polly's parents instead advocate divorce for her. Let analyse the ironic representation of love in a capitalist society by Brecht:

POLLY: Please consider him. Is he handsome? No. But he makes a living. He offers me an existence. He is a firstclass burglar, a far-sighted and experienced street-robber. I could tell you exactly what he's got saved up. A few more successful enterprises and we can retire to a little house in the country, just like that Mr. Shakespeare father admires so much.

PEACHUM: Well then, it's all quite simple. You are married. What do you do when you're married? Don't bother to think. You get a divorce. Eh? Is that so hard to arrange?

POLLY: I don't know what you mean

MRS PEACHUM: Divorce.

POLLY: But I love him, how can I think of divorce? MRS PEACHUM: Aren't you ashamed of yourself?

POLLY: Mother, if you've ever been in love....

MRS PEACHUM: Love those damn books you've reading have turned your head. Polly, everyone does it!

POLLY: Then I shall be an exception.

Specifically, love takes the form of business deal in the social order presented in Brechtian vision of capitalist society in the selected play text. Like any business deal it is based on contractual agreement and profit. Polly being an integral part of a capitalist society understands the value system therefore, throughout her active engagement in the form of discourse with her parents tries to persuade them with her financial understanding of the 'love relation'. She points out the Macheath's exact saving and future prospects due to his insight and business acumen. However, she misses two key points. Firstly, since Macheath is a competitor to her father, Peachum, both her parents selected this emerging opportu- 
nity to ruin Macheath both financially and physically and secondly, her utility as the 'means of production' in the eyes her parent is shown in a few dialogues in the selected play.

One can argue that Brecht saw as an astute political analyst who was diligently attending the communist party meeting at this time in late 1920s he was analyzing the outcomes of this corrupt capitalist society. While, Nazi movement emerging on the political scene, his prime voice, Adolf Hitler, with the financial support of "hard core disaffected sections of middle class" (Welch 1993) and criminals like "Macheath and Peachum", stressed profit orientation and freedom for big business especially banks with pro-capitalist agenda. Brecht used the theatrical space to alarm Germany ahead of his times.

Contextual reading of historical documents reveals that until the summer of 1932, when unemployment reached an estimated 8 million (or roughly one -third of the working population), government response to the economic crisis was to 'starve' the economy into the health by cutting salaries, wages and public spending, including welfare and un-employment benefits (Evan \& Geart 1987). Then finally, Rosenhaft writes in article Brecht's Germany: 1898-1933 that NSDAP rose to power and "with many other artist and intellectuals, Brecht was quick to draw the consequences from Hitler take over; on $28^{\text {th }}$ February, the day after the Reichstag fire, he left Germany and did not return permanently until 1949 " (20) exactly after twenty years he staged the capitalist society of Germany under the fear of emerging pro-capitalist Nazi movement.

Hutcheon (2006) points out that the significance of "ideological motivation" (94) in adapting certain texts. Like Brecht, Ajoka theatre also saw the 'political price' of living in Pakistan under "inhumane capitalist and authoritarian policies" (Nadeem 2007). Zia ul Haq regime transformed the very fabric of the tolerant society like Pakistan by keeping the capitalist ideology in the center of its economic policies during 1980s. Series of economist noticed the rise of "Punjabi capitalist class" during General Zia -ul-Haq regime (Wiess, 1991, Sayeed, 1990, Rahman 2012). Capitalist class changed the rules of game of politics in Pakistan (Sidiqa 2009). Rehman (2012) in his seminal work on the class structure of Pakistan indicates the birth of neo-liberal economic framework for Pakistan:

From the 1980s onwards, the economic policies continued to move towards neo liberal reforms. In spite of the return to democracy in 1988, as a result of mysterious death of General Zia in a plane crash and the formation of a new PPP government led by Benazir Bhutto, government policies continued to implement IMF-negotiated Structural Adjustment Policies (SAP). Neither the ostensibly left of the center PPP, nor the conservative Muslim League, nor the military dictatorship of General Musharraf, altered this fundamental neo-liberal economic framework. (220)

Therefore; due to capitalist policies in the form of neo-liberalism, we continue to visualize the presence of "London soho" in every city of Pakistan and observe why Ajoka adaptations are so popular in Pakistan in general masses. "Paki- stani's see and enjoy Mac the knife (Fooka Terror), Peachum (Abdul Faqeer)in the theatre and fear and abhor them outside of the theatre, the real question is who will stop them" (Nadeem 2005).

It is interesting to compare the political and culture factors in Gay's The Beggars Opera and Ajoka's Takey Da Tamasha because of the distinct similarities in 'power politics' behind these two literary works. In John Gay's one of the central character Peachum was a lampoon of Robert Walpole, the first Earl of Oxford (1676-1745), known before as 1742 as Sir Robert Walpole, was a prominent British statesman who is generally regarded as the first Prime Minister of Great Britain and described by "contemporary opponents as the 'Screen Master General', adept at pulling all political strings" (Thomson 2014). Following the same vein, Macheath, the swashbuckler, was a lampoon of Nawaz Sharif who was the Punjab's chief Minister at the time of adaptation and later became the Prime Minister of Pakistan. This hidden political element in both John Gay's work and Ajoka's adaptation risked censorship and banning.

Secondly, Gay's satire was against class distinction and members of the royal court because he presented the harlots, burglars, and cutthroats are as important as the national statesmen. These low- lives have the manners of proper English Lords and ladies, and they gain power in much the same ways, thus debating the human nature. Ajoka theatre in a same manner highlighted those harlots in 'red light district Tibi' in Lahore which represents the same kind of ethics and manners the Bourgeoisie class displayed since they were the 'illegitimate' sons and daughters of the same class.

\section{REPRESENTATION OF NEO-LIBERAL POLICIES IN ACADEMIC STUDIES IN PAKISTAN}

In recent years, several studies have focused on the effects of neo-liberal policies and have confirmed the negative effect of them on Pakistani society. The aim of this parallel reading of these academic studies is to examine how Takey Da Tamasha (1989) and Burqavaganza (2007) connects or detach with these social sciences researches dealing with the capitalism during the same period.

Shah (2007) points out that far from improving efficiency, these neo-liberal reforms were accompanied by a decline in the rate of growth in certain key industries. For instance, the textile industry sustained a loss of an average of 3 percent during the period 1995 to 1997. (477)

Bashir (2003) indicates the impact of neo-liberalization on agricultural exports was relatively modest (956). Bonaccorsi di Patti \& Hardy (2005) exhibited that financial sector liberalization only produced gains in profit efficiency in the period immediately following privatization. In subsequent years, only one private bank could be differentiated from state-run banks in terms of profit efficiency. (112)

Similarly, Khan (2003) shows that the impact of privatization of industry was negative on both employment and on output (530). Siddiqui and Iqbal (2005) stated that trade liberalization had a long running negative relationship to output (101). Anwar (2002) detailed study demonstrated that, in the 
case Pakistan, not only liberalization not improve growth but it contributed to increasing unemployment, poverty, decline in the growth rates of large-scale manufacturing, loss of government revenue, and increasing indebtedness. (17-18)

In a different study, Muhammad Waseem examined bourgeoisie class role in controlling the resources of the country. He presents a comprehensive review of the authoritarian rulers of Pakistan's history and indicates an important finding that with the exception of Zulifqar Ali Bhutto all Pakistan's authoritarian rulers such as General Ayub Khan, General Zia-ul-Haq and General Musharaf have been drawn from the bourgeoisie class. "There 'stock in trade' is that democracy has been 'hijacked' by the feudal, politicians are 'corrupt' and Pakistani society is yet fit for democracy." (34)

Talbot (2012) recognizes Waseem views provide a "useful counterpoint to the more widely held belief that the rise of the middle class in Pakistan will go hand in hand with democratization and liberalism." (35)

We see the Waseem's exclusive discourse on middle class which harbor businessman turned politicians is clearly reflected in both of the adaptations of Brecht's play in Pakistan. Spirit of Iqbal, Siddiqui, Bashir studies are seems also reflected in critique of capitalism in Ajoka's transcultural adaptations.

\section{SUCCESSFUL PERFORMANCE HISTORY OF THE THREEPENNY OPERA IN PAKISTAN}

According to Hopkins (2016), one of the main suppositions of New Historicism is that "literature doesn't exists in a previldged realm of its own but is fundamentally connected to the political world outside of it (72). In Pakistan, TOO was first presented under the Takay da Tamasha (One Penney Show) by Ajoka theatre in collaboration with the Goethe Institute, Lahore, in June 1989, just after the restoration of democracy in Pakistan. The performance history of Takay da Tamasha in History of Ajoka Theatre (2010) exhibited that it ran for three weeks due to audience demand. Since its premier performance, the play has been performed several times by Ajoka which indicates its success among the Pakistani audience. Ajoka version of the Brecht's story is both highly theatrical and strikingly original.

One of the most significant current discussions in adaptation studies is effect of transcultural element which according to Hutcheon has the potential to change the meaning of the source text (99). The most striking feature and lasting fascination of this adaptation is the politics of location. Ajoka located the play in inner urban Lahore's Tibbi district. Interestingly, with its proliferation of prostitutes, pimps, gangsters, beggars, shady characters, dark alleys, drug pushers, it can be taken as Lahore Soho. In Takay da Tamasha's characters were representative with local names to give the play indigenous touch. Mac the knife becomes "Fooka terror" of today's Tibbi, and it is not difficult to see the contemporary political and social relevance of the play to contemporary Pakistani capitalist society. Ajoka theatre in the transcultural adaptation seemed eager to center on Mac the knife (Fooka Terror) as the new 'capitalist mind set' on the political horizon in Punjab. Specifically, Nadeem, the adapter of the selected play was eager to call the adaptation "Fooka Terror" but the dramaturg Madeeha Gohar convinced him to go with the title Takey da Tamasha which reflected the same kind of feeling as The Threepenny Opera and to develop another adaptation with Arturo Ui in a getup of Fooka Terror to satisfy him. He finally got convinced (Rumi, 2010). It is pertinent to note that 'Bank' is also one of the key symbols of capitalism. Talbot (2012) noted that and highlighted:

Nawaz Sharif also posed as the protector of Punjab's interests and the upholder of provisional autonomy, On 15 November 1989; he inaugurated the Bank of Punjab with its own paid-up capital of Rs.100 million. The PPP called this act unconstitutional and treason against the federation. In reality the Punjab Prime Minister was operating legally, but the symbolism of the bank's logo, the rising son royal insignia of Maharaja Rinjit Singh, the last ruler of an independent Punjab, was not lost on his opponents. (161)

It is interesting to note that Fooka the terror explains the his 'philosophy' of Banking business which was the corner stone of Nawaz Sharif tenure in office in following interesting and thought manner by engaging the audience in Scene 9:

We lower middle-class artisan who toil with our humble sohnas (person who is loving, caring and girls loves to date him) on small shopkeepers' cash registers are being swallowed up by big corporations backed by banks. What's a sohna compared with a share certificate? What's breaking into a bank compared with foundation a bank? What's murdering a man compared employing a man?. (76)

Baker (2005) in his book, Capitalism's Achilles Heel also verified the Sharif's love for banking business and especially for the loaning facility as a free cash to strengthen his business empire:

Under Sharif, unpaid bank loans and massive tax evasion remained the favorite ways to get rich. Upon his loss of power the usurping government published the list of 322 of the largest loan defaulters, representing almost $\$ 3$ billion out of $\$ 4$ billion owed to banks. Sharif and his family were tagged for $\$ 60$ million. The Ittefaq Group went bankrupt in 1993 when Sharif lost his premiership the first time. By then only three units in the group were operational, and the loan defaults of the remaining companies totaled some 5.7 billion rupees, more than $\$ 100$ million. (83)

It is highly interesting to note that in Panama Paper Scandal Case against Nawaz Sharif and his family, Supreme Court of Pakistan allowed the plaintiff to use this particular book as evidence.

While setting Takay da Tamasha in the historical context, we observe that Ajoka has created characters representing the political views of the time. Ajoka took notice of Sharif's 'intimate' relationship with banking industry. The event to launch a bank re-kindled the fire in them. Ajoka took advantage of the opportunity and especially showcased the symbol of Bank to highlight the capitalist imagery as we know banking sector was considered safer and more profitable by Fooka terror since thieves like him were being edged out 
the market by big business and banks. Actors pointed out it by repeating this dialogue between Fooka Terror (Mac the knife) and Peeno (Polly) again and again. The Nawaz Sharif loyalists took notice of it and stormed the venue and closed the doors of Alhamhra art theatre before just few hours. They asked Nawaz Sharif to ban the play since they knew Sharif's way of managing affairs - "strong arming his opponents into submission” (Nasr 2009). No doubt, Fooka Terror getup and voice tone and body language (especially pointing one finger upward) was just like him. Here are these memorable and Provocative dialogues repeated loudly in typical Nawaz Sharif style to create impact and connection:

PEENO: I am so happy, Fooka g!. You think of me jaani (beloved) when they're after you like mad dogs [then she starts cursing them in local language]

FOOKA TERROR [loudly intentionally]: Listen dear listen! Send all to the profit to Punjab Bank in Tibi. Between our self, it's only a question of weeks with blessing of Allah before I switch to banking exclusively it's safer as well as more profitable. Ha ha! Peeno g (then he dances on the stage and hugs Peeno with joy]. In two weeks at the most the money must be out of this business. And you go to D.S.P Delawar and hand the long list of names to police. In four week at the most, all this scum of the earth will standing their trail at the Old Session Court.

PEENO: But Fooka g! How can you look them in eye when you are going to double-cross them like this and have them as good as hanged? Can you still shake them by the hand?

FOOKA TERROR: Who? Sheeda Churi(Hook finger Jacob), Mooda Stain (Money Matthew), Jaji Bhond (Robert the Saw), Kooma Qainchi(Wally the Weeper) ...those gaol -birds?

One of the striking features in the performance of Takay da Tamasha is the adaptability of Brecht's Epic theatre in an Asian landscape which also played a key role in the successful reception of this adaptation. It is also pertinent to note that Brecht's theatre bears the signatures of traditional subcontinent theatre in form of style and elements (Gupta 2013). Likewise, Madeeha Gohar, as a dramaturg, instead of claiming Ajoka's distinct adaptation capability in transforming a literary piece from western to eastern hemisphere expressed and appreciated close technical association of Brecht's theatre with Asian theatrical heritage thus validating Erika Fischer- Lichte point of view in Syncretic Theatre (2007) that the "fundamental and far-reaching renewal of European theatre which occurred in the first decade of the twentieth century appears to be not the least consequence of a conscious an productive encounter with theatre tradition of foreign culture." (30)

Brecht's discovery of the immense possibilities of Asian theatrical traditions as opposed to the rigidity of Western Realism, led to his exposition of a theory of aesthetics of theatre which changed the form of modern theatre. Though his work as a playwright and a director he created a new sensibility in $20^{\text {th }}$ century theatre. A dry doctrinaire didactic theatre was far from what Brecht had in mind, and is often mistakenly assumed. Enjoyment is the noblest function we have found for the theatre" he said. But if the audience is to enjoy what is learn in the theatre, it must be detached and critical. This alienation of the spectator is achieved through various techniques including the detached acting style, the intrusive music and dance and storytelling in Epic Theatre. (2)

Hutcheon (2006) presents enormous challenges in indigenization process. She states that "Adapting across cultures is not simply a matter of translating words. For audiences experiencing an adaptation in the showing or interacting modes of engagement, cultural and social meaning has to be conveyed and adapted to a new environment through the body language" (149). Ajoka Theater took many liberties in transcultural adaptation of The The Threepenny Opera. It is by no means just a translation of Brecht's play. The London setting is replaced by mock-Soho in Lahore, Pakistan. Scenes are added to reflect in life of red light area. In an effort to draw out the parallel even further, Ajoka current production has extended the Brechtian technique of alienation effect (the distance of the actor from the character) to the typical acting style used in Pakistani cinema which is typified by large than life characterization. Ajoka theatre turns the venue of the play from Berlin to the "walled city" of Lahore. Actually, Pakistani theatre has taken Brecht's selected play a step further by introducing pivotal elements from indigenous South Asian cinema and theatre. The utilization of typical Pakistani loud style of acting in performance of Brechtian drama is innovative and exhibits the experimental quality of Ajoka theatre.

The stage setting was also catchy and created an ambience for audience to be a part of that soho. This however against the stage directions of Brecht who always argued suggestive design for his play this design was also theoretically different from CC, the first adaptation of Brecht's CCC in 1985. As the back drop to the stylized acting in adaptation, Ajoka has tried to use popular "visual truck art" with helped to create the ambience of Lahore the audience knew existed in the night fall. The visual backdrop of famous indigenous Truck art served the cultural identity of the play imparted a local and homely quality to the performance.

Ajoka does not end the play as Brecht does but takes it further where the Queen announces a grant of one billion for the social services that Fooka rendered during the autocratic regime. The queen also confers on him a medal of democracy, and the play ends with Fooka Terror transforming into a democratic national hero.

Accepting the challenges of indigenization and turning them into opportunities has resulted into theatrical success for Ajoka for instance, the linguistic strategy, the adaptability of Brechtian theatre into typical Asian theatre and lastly the environmental uncertainty due to the emergence of martial law which welcomed the radicalization of theatre in Pakistan.

\section{EMERGING CAPITALIST PAKISTANI SOCIETY: PARALLEL STUDY OF NON-LITERARY TEXTS}

Greenblatt (1985) in Genre, proposed that in order to understand literature one has to take recourse to both culture and 
society that gave rise to it in the first place (118). In 1990s we see a rise of electronic media in Pakistan which became the engine of dominant discourse for the establishment and a right wing bourgeoisie class. It can be argued that the rapid and unprecedented growth of electronic media under General Musharraf period provided financial stability and creative energy to a state's version of progressive capitalism and consumerism. It also provided strong platform to curb the dissident secular and pro-democracy voices coming out of alternative theatre.

New analysis programs with claims of "unleashing the truth and only truth" loaded with the fully funded heavy advertisements of big business and multi-national companies. Ian Talbot (2012) argues that they become part of problem rather than part of solution in Pakistan: A New History and declares electronic media voice of existing orthodoxies in harboring fundamentalism in Pakistan:

A new cable networks have, however, strengthen existing orthodoxies in many instances, rather than interrogating them, and in the eyes of some critics have contributed to the powerful anti-western discourse in contemporary Pakistan. Increased media access has in fact provided new opportunities for the spread of conspiracy theories, which are marked feature of Pakistani public life. According to some commentators, they reflect a wide spread national malaise which by denying the root causes of Pakistan's problems prevents any attempt to address them. (31)

Another ground breaking study to view the emerging trend of religiosity in the middle class is Mohammed Waseem's article "A Tale of Two Classes" (2009) in leading newspaper, Dawn. He asserts that it is the rightist middle class which is moving toward religious fascism. He furthers argues that the absolute majority of middle is rightist, although lawyers, writers and intellectual comprise a small pro-democracy element within it. The rightist element is made of military officers and bureaucrats, engineers, architects, corporate manager and businessmen all of whom are intensely conservative in outlook (34). Waseem point of view resembles with Ajoka theatre discourse in Burqavaganza, the recent adaptation of The Threepenny Opera which highlights the growing trend of religious fascism among young female population in $\mathrm{Pa}-$ kistan:

Indeed, one of the most striking developments of the past decade has been the spread of the orthodox Al Huda movements amongst educated middle-class Pakistani women. This has prompted the Arab dress code of the full-size abaya. (30)

The rise of conservatism in bourgeoisie class is also examined by Talbot in Pakistan: New History (2012). He pinpoints one of ignored and less research factor of overseas migration especially short term movement of Pakistani semi-skilled workers to Middle East from 1970s and 1980s. According to him this increased the size and scale of middle class wealth in Pakistan. He also indicates the psychological reactions arising from the frustrations of newly-enriched returnees have been dubbed the Dubai Chalo (Let's go to Dubai) theme in Pakistani society:
The cultural impact of overseas migration is much less quantifiable than its economic consequences. The growing religious orthodoxy coincided with the increase of labor migration to the Gulf and Saudi Arabia in the 1970s. Assessments of the Arabization of Pakistani Islam tend to focus on the Saudi export of Wahhabism in the political context of Iranian revolution and the Soviet occupation of Afghanistan. In doing, they overlook the influence of growing numbers of migrant oil and construction workers who returned home to scriptural Islam in opposition to popular 'folk-Islam'.

In opposition to Marxism, Vali Nasr's book (2009), The Rise of Islamic Capitalism appears as a highly significant document which "brilliantly narrates the tortured histories of middle classes in Pakistan and Muslim world" (The New York Times Book Review, 2010). In the back drop of socio-religious development in Pakistan in three decade and to view what is the emerging dominant discourse in Muslim world spread by the enlightened scholars from America which is to align Islam with capitalism by pinpointing Dubai and Turkey as a model. This alignment is highly suitable for the capitalist west which sees her multinational companies flourishing in the name of Islam and with the aid of "pious" middle class:

The ability to stay true to Islamic values even while pursuing capitalist dreams is essential to its success. The Dubai experience builds on similar experiments in Malaysia and Turkey, where development has also relied on the releasing the entrepreneurial energies of the new and pious middle class, through a blending of the values of Islam and capitalism. (32)

Dedicating one whole article to Pakistan socio-economic conditions, Nasr (2012), professor of international relations at the Fletcher School of Law and Diplomacy of Tufts university, advises the West to advance and support Capitalist ideology for Pakistan by encouraging its bourgeoisie business class that he sees as "The Prophets of change" (176) and "key to defeating extremism" (180) in particular:

The west can work to help strengthen the vital center in Pakistan by focusing not just on its military and political elite, but on strengthening the middle class that is true force for moderation and a pillar of democracy. That requires a stable and growing Pakistan economy but more important is strengthening entrepreneurs and businessmen by providing them with financial support and the access to global markets they desperately need. Pakistanis are capable of getting the job done. When outside their home country, in Dubai, London, or New York, they are every bit as competitive as Indian or Chinese business people. It is back home that constraints hobble them. (231)

Terry Eagleton (2011) counter this "prosperity discourse" by citing the "staggering human cost" countries bear in order to chase capitalist dream in his book, Why Marx Was Right and he further declares the consequences of this careless capitalist attitude can ends up in form of climate change which has the potential to destroy the whole humanity:

It is true that capitalism works some of the time, in the sense that it brought untold prosperity to some countries 
of the world. But it has done so, as did Stalin and Mao, at a staggering human cost. This is not only a matter of genocide, famine, imperialism and the salve trade. The system has proved incapable of breeding affluence without creating huge swathes of deprivation alongside it. It is true this may not matter much in the long run, since the capitalist way of life is now threatening to destroy the planet altogether. One eminent Western economist has described climate change as the greatest failure in history. (15)

Nasr concludes his grand personal narrative for capitalism which can like act like an active 'antibiotic' or the sick soul of Pakistan and would immediately "solve" the rapidly growing terrorism issue in Pakistan if America realizes to facilitate the new "dynamic and upwardly mobile middle class entrepreneurs and reformers"(302). He consolidates his pro-capitalist argument by saying:

When in March 2009 Tahrik-e-Talban (Pakistan's home grown Taliban) brazenly attacked a police academy outside Lahore, killing several recruits and leaving little doubts that extremism was determined to take down the Pakistani government, I called an old friend in the city to see how he was and what had happened. My Friend is a big businessman, with holdings in textile and food products, American educated, but also religious. "They are murdering this country one bullet at a time" he told me forlornly. What can be done? I asked. I don't know what we can do" he responded, but I know what you can do [referring to America]. Lift all those tariffs; that will help". He had explained to me many times before, "Grow the economy; the rest will sort itself out". (263)

His discourse is highly significant to this study to analyze both entirely different yet equally powerful discourses which have equally influence the Ajoka's production of the anti-capitalist and pro-secular plays. The politics of behind these plays is to counter this emerging discourse creatively. It is also pertinent to note the growing frustration in Ajoka camp when Nadeem sees the growing strength of pro-capitalist forces hiding behind the so-called Islamic forces in $\mathrm{Pa}-$ kistan who have become self-apologetic or in other become key supporter of non-tolerant behavior in in Pakistan:

The play is set in contemporary Pakistan where 98 percent of the population is Muslim, mostly religious in belief if not in practice. In the late 1970s, Islamic parties, which had been peripheral until then, were co-opted by the establishment with the blessing of the West to wage a jihad against the soviet forces in Afghanistan and to consolidate military rule within Pakistan. Because of variety of domestic and international factors, these fundamentalist parties have become powerful, politically and militarily. They have a larger vote bank than ever before and have a fantastical following in the country. (282)

Ayaz (2013) in What's wrong with Pakistan? seems to endorse Nadeem's discourse on rising Islamic bourgeoisie society in Pakistan. They argue that Pakistan is becoming increasingly polarized between the Islamist who receive considerable state patronage and liberal democrats who are on the defensive side. They point out that this enormous strength is due to nexus between capitalism and growing religiosity among masses in Pakistan in general and Punjab being the biggest province in particular.

However, historians Talbot (2012) and Hasen (2010) in the thesis entitled, Radical Rhetoric-Moderate Behavior, partially disagrees with him who thinks despite increasing orthodoxy, Islamic parties have polled badly in national elections. He argues that with the exception of 2002 which was marked by state intervention on their behalf. Islamic parties have growing leverage, but "this rested on their 'street power' and links with the military establishment, rather their ability to convince Pakistani voters" (39). These comments also exhibit that may be Ajoka theatre is exaggerating in its response to religious extremism in Pakistan. It is important to note that funding of these plays was done by Royal Norwegian Embassy and German nonprofit organization (Ajoka Brochure 2010). These organizations promote secularism and inter-religion harmony. This also indicates the supports Ajoka enjoys among western countries due to its secular agenda.

Similarly, Khan (2007) also passionately pinpoints a growing nexus between post-modern capitalism, and religiosity (Patriarchal ideology) to suppress women rights and highly appreciates alternative secular theatres especially Ajoka for body counter it. She thinks that "cycle of oppression arising out of the alliance of capitalism, patriarchy and religiosity - an alliance crushing both women and working class men" (109) can be addressed through Brecht's social and political philosophy which has played a big role in developing their theatrical vision and resistance to the dominant discourse. She wishes:

I wish to explore further the connection between post-modern capitalism in the era of globalization, and the return to conservative, traditionalist attitude towards life (the postmodern/traditionalist dichotomy) which converge to keep oppressed in Third World countries in Pakistan, which have witnessed the rise of Islamic fundamentalism in the last three decades of the $20^{\text {th }}$ century. These connections and complex convergence of postmodern economic and socio-cultural factors and their ideological underpinning, which are contributing to the rise of seemingly anachronistic or pre-modern fundamentalism around the globe, with Pakistan being simply the particular case should be scrutinized. (91)

This study with endeavors to investigate the nexus between capitalism and religiosity and dictatorship seems to be the 'direction' in which she passionately asserts that there is a need for further research. This section of the study explores these three above mentioned issues in the light of Brecht's work and its transcultural adaptations in Pakistani context.

Babar Ayaz (2012) a prominent journalist pinpoints the dilemma of Pakistani society in general. He suggests secularization of Pakistani society in order to address the social and political issues emerging in the contemporary Pakistan:

This is true as the Pakistani society is going through a metamorphosis - and is torn between the conservative Islamist society values and the modern globalized liberal society demands. (199) 


\section{BURQAVAGANZA: SATIRE ON ISLAMIC CAPITALIST SOCIETY THROUGH BRECHTIAN THEATRICAL MODEL}

In Pakistan's context, one of the most perplexing questions that remain problematic is role of religion in a state (Talbot 2013). As a secular theatre, it can be argued that Ajoka showcased Islamic capitalist society in the 'spectre' of what it has envisioned is 'coming out' the corruption, contradiction and double standards of the dysfunctional society which uses religion as tool. However, Sirajudin (2008) views this thematic concern as Ajoka's long standing vision:

The close proximity of religious orthodoxy with political oppression and material aggrandizement is a major theme in the playwright's work. (x)

The play as the title suggests, is a 'musical comedy' or 'Maach' designed to criticize the so-called "morality brigade" which dominant since Zia's takeover in 1977 and changed Pakistan into intolerant nation. Structurally speaking, however, this play is more of adaptation of Brecthian Epic theatre. Leach (2008) detailed description of Epic theatre appeared in his book, Theatre Studies 'came to light' in this play. According to his definition of Epic theatre which I argue Burqavaganza can be cited as an "Asian model" of Epic theatre:

Epic drama has been always been characterized by public concern; it issues are not private, nor indeed are they social in the usual sense. They are political in fundamental way, addressing the problem how we shape our community. Their typical feature includes largeness of size and scale; frequent uses of meta-theatrical devices, such as narrators, songs and so on; a hero has tends to be representative, and therefore not particularly interesting as an individual; and a structure tends to be episodic, relying on fable, montage and gestures for its effects. Twentieth -century epics especially often have open endings, and employee Brechtian alienation techniques so the spectators are encouraged to consider the issues rationally. (62)

Similarly, it can be argued that Ajoka's Burqa Vaganza is characterised by public concern of the unprecedented rise of the so-called Islamic bourgeoisie society hiding behind burqas and fundamentalist ideology, 'brainwashing' the youth to take 'violence as a solution to every problem' (Pakistan lost 50,000 young men and women due to the bombasts in just one decade) and put Islam as a cross-reference. Ajoka utilized this burning issue to highlight its political stand of a "secular nation and state" (Ajoka brochure 2005) to showcase its community fundamental right to enjoy healthy relations such as love to represent its true Punjabi identity. It must be noted here that traditional Punjabi literature entails many love stories.

Beyond political dimension of Burqavaganza, Hussain (2011) a renowned novelist and cultural critic sees another aspect of this particular Ajoka production which is to provide pure entertainment. He highlights this aspect with this statement in his article in History of Ajoka Theatre: "In Burqavaganza the playwright manages to permit his readers and the audience the luxury of an amused smile. Occasionally, they are also allowed a hearty laugh" (42). This, however, also exhibits the Brechtian theatre vision of combining entertainment with education.

In addition, frequent use of meta-devices was used such as Bollywood songs and dance and gestures give it a largeness of size and scale. It was open ended and episodic in nature comprised of 20 scenes instead of 'Acts' which is a dramatic structure used in naturalistic plays. It explored "Burqa" as dramatic attire but also used it as a metaphor. This metaphor was explained in detail by Nadeem himself after he was severely criticized by the religious segment of female elite in National Assembly and Senate:

After all we don't just cover women in the covering burqas. We hide a lot more. We cover up the individual or collective ugliness under ideological or patriotic burqas. The primitive values system is hidden in the burqa of tribal culture and tradition. The beast of terror wears a spotless and noble shariati burqa. Who hides behind the police uniform or a doctor's gown? The feudal despot conveniently adorns a democratic burqa when needed. (11)

Broadly speaking, Burqavaganza is also a story of love in the "time of jehad" (Nadeem 2008). It is the stories of young lovers who are determine to defy the hypocritical values of an ultra-conservative society. Like all lovers they want to spend time together only to be interrupted and to be harassed by the 'moral police' and the stick -wielding burqa brigade. The love blossom with the help of popular film songs and under various forms of burqas, while the world outside is falling apart because of the war on terror and a search for Burqa bin batin. It is a world where lovers are persecuted and terrorists are worshipped, where new technology is used to promote out-dated and retrogressive ideas:

In a society like our, a bold and beautiful was bound to land into trouble under an intolerant and retrogressive regime wearing the burqa of enlightment but Ajoka and its devoted audience refused to be cowed down by such cultural terrorism. The play was performed in defiance of the ban and eventually the Government back off" (Ajoka official Press release on April 11, 2010).

According to Foucault (1995) in Archaeology of knowledge, power and powerless are not fixed positions. The balance of power can be disturbed by reversing the discourse. Once powerful may become powerless and once powerless may become powerful at another point in history and the distinguishing factor between powerful and powerless is discourse. There seems to be constant struggle for the possession of discourse in order to possess or regain power (87). Ajoka's discourse on 'exploitation of Islamic ideology' at the hands of emerging 'pious' bourgeoisie class to acquired 'new' meanings in the time when Pakistan suffered heavily due to suicidal bombings in "War Against Terror" (2001-till now). It is fact that majority of the suicidal bombers bodies recovered, male or female, used burqa as an 'attire' to hide them from the security forces. It seemed appropriate time to challenge the constructed 'pious' representation of capitalist Islamic bourgeoisie class during the "war on terror" which was already legitimized through various social institutions 
and became 'convincing reality' in the Pakistani society through a discourse of 'national interest'. Ajoka realized the significance of time and space and use the discourse of 'secularization of society' to shift the advantage in their favor "as there points of resistance available within the process of power for the act of resistance" (Foucault 1995).

In Foucauldian spirit, this inventive play is highly subversive and brutally harsh in its satirical attacks in content as well as in the description of its "production notes" which can be a good source to view how Ajoka tried to cut short the image of the so-called pious middle class well established and documented by Nasr (2009):

1- The play has been conceived as an extravaganza with exaggerated acting, parodies of popular film songs, screen images of 'Burqa Vision' telecast, and sexy dances by burqa-clad actors. A production will work belter if that style is adopted.

2- The set for the play was a huge black cut-out of a sinister looking black burqa with arm extending to the right and left edges of the stage. The big panel at the back of the maulanas sitting on the edges contained images of beautiful women, sweet girls, and colorful flowers with remain hidden by crowds of burqa clad women till the end of the play when actors tear the cover away to reveal the beautiful images. The message is obvious.

3- The Hijab Hashmi Phenomenon: A new phenomenon in many Islamic countries is the appearance of charismatic women scholars who have a cult following among bourgeoisie class women.

4- The photographs of real political leaders and used in scene 21 . They were all hanged or assassinated where international (read American) involvement was suspected. At the end actors remove their burqas, not to reveal their faces but masks of important personalities dominating the national and international scene, give a rather obvious political dimension to the play. The personalities, of course, can keep changing to the situation. (Selected Plays Shahid Nadeem 287-88)

The next important thing revealed through these 'production notes' that sex which is being treated as a 'taboo' and 'sin' by the bourgeoisie class is actually a 'natural' and 'cultural' phenomenon' which can be exhibited by the sexy dances with sinister burqas. Images of beautiful girls, sweet girls and colorful flowers depicts as the inner desires of this class which they hide from other and forbids everyone to even think about them. The Hashmi Hijab pinpoint towards Dr.Farhat Hashmi who started Huda movement "aiming to educate elite women about their rights and responsibilities as a good Muslims. It was founded in 1994 by Dr. Farhat Hashmi when she returned to Pakistan from UK" (Talbot 2012). It is worth noticing the California Killing of 14 innocent Americans in 2015 was executed by the Pakistani female pharmacist trained at al Huda foundation in Multan Pakistan which shows the influence of this kind of conservative discourse and its consequences.

Similarly, Nadeem's stage directions refer to the political and social environment of the 2000s in Pakistani context. The detailed stage directions introduced in the play are quite unique in their scope and effectiveness. They do not only illuminates the theatrical aspects of the play's production besides exposing the representative make-up of its characters. In addition, it is also pertinent to point out the subversiveness to present the burqa clad middle class double standards and hypocritical nature in comical way for example the stage directions is the first scene highlights the role of stage direction in the understanding of the play's political message:

A huge cut out of a black burqa dominates the stage with a video screen in the middle. The arms of the burqa extend to right and left wings of the stage. On the two wings are displayed two panels of images of burqa clad women. Two mullahs sit in front of a panel. All characters in the play, except the mullahs, are clad in burqas or masks of various kinds. For example, the young lovers wear modern, designer burqas, the police wear masks attached to their uniforms caps and chorus wear old-fashioned Afghan style shuttlecock burqas. Characters appear on stage in their burqas and masks in pair. They strut like fashion models and exit. The screen shows scenes from similar burqa cat walk. (289)

Ironically, vivid capitalist images like "modern designer burqas", colourful masks, fashion models and burqa cat walk" are used to frame the capitalist Islamic middle class in the same line with the liberal working class by giving them the same out-look. Variety of burqas exhibits that each segment of bourgeoisie class has its own kind of cover-up. By illuminating them through the 'same fashionable symbols' they actually showcases the contradiction and the double standards of the newly emerged religious class created in the aftermath of Afghanistan war fully funded by America. These provocative yet innovative images presented in hilarious way is to send a bold and clear political message and to initiate the discourse of resistance that we are not afraid of you and there is no 'sacred cow' in Pakistan.

According to Huchteon in preface of Theory of Adaptation (2006) "neither the product nor the process of adaptation exists in a vacuum: they all have a context-----a time and a place, a society and a culture" (xvi). In Burqavaganza, Ajoka sets out to define all of the features Hucheon represents in context. With religious fundamentalism on a rise, Ajoka observes the drastic change in the outlook of the society and consequently understands the deterioration of cultural norms and values along with it. Ajoka wants to highlight double standards in the so-called bourgeoisie middle class where lovers have to cheat their parents to show high morality. Furthemore, love is a transaction of visible moral values displayed on powerful and growing electronic media which ironically nobody believes but are doing it for the public in large. Everything is fashionable as long as it is in burqa.

Scene 15: Couple Rendezvous

Has: Khaobrboo!

KHOOB: Yes, Khoobroo's beloved

HAS: You know my parents are coming to see you

KHOOB: Really? And did I tell you, my parents liked your picture.

HAS: Which one? The one in the pink burqa

KHOOB: No, the one with the shuttlecock burqa. My 
mum said, I want a conservative daughter in law and she seems to be the one.

HAS: But she doesn't know that inside this old-fashioned burqa, I am quite modern.

KHOOB: You should not tell your folks that I act in Burqa vision plays, either.

HAS: Do you think I'm fool ? But you be careful. Your serial is on air on these days. What is it called?

KHOOB: 'Hijab was once a Burqa'. Episode 205 will be on air any minute now.

HAS: Let's watch it then, Press the button

Foucault, one of the most significant forerunners of New Historicism, also argues that power operates through continual classification, re-classification, surveillance and intervention. The power of religion as we see in the case of Burqavaganza is exercised through moral imperatives and the right behavior, including behavior in a public sphere.

\section{CONCLUSION}

This article was written to determine the effects of Brecht's The Threepenny Opera and its transcultural adaptations as 'contextualized cultural products' in Germany and Pakistan in development and propagation of the Marxist political thought in their historical framework.

One of the significant findings to emerge from this study is that these adaptations are 'socio-historical' documents of their periods. The Threepenny Opera depicted the societal conditions ripped for Nazism in Germany while, in case of Takay da Tamasha and Burqa Vaganza if read together, presented the 'nexus' between capitalism and religiosity which gradually transformed the Pakistani liberal and secular society. Therefore, their social and political value seemed multi-folded: they were highly subversive to the status quo and boldly experimental in both form and content in their representation of the Capitalist society.

The second major finding was that the adaptations forcefully questioned the political and economic positioning and actions of emerging powerful capitalist society with a spectre of dictatorship as an ultimate out-come. The findings from these study make several contribution to the current literature, First, by conducting parallel study of selected non-literary texts from the same historical period along with the selected texts as suggested by Greenblatt approach to new historicism (1985), a "mutually illuminated relationship" (77) has been discovered and justified. Secondly, now, it could be argued that diametrically opposed to capitalism, Brecht analytically feared in 1928 that Nazism would emerge out this capitalist society of Weimar republic while Ajoka prophetically thought in 1989 the Zia regime just 'buried' few years ago would be 'resurrected' with Zia capitalist protégé, Nawaz Sharif. To gauge the audience before time seemed the 'hidden' politics behind these selected adaptations.

Furthermore, Ajoka by 'indigenizing' Brecht's radical Epic model and adding one more highly sensitive Focauldian variable in Burqavaganza i.e. power of religion to support capitalism. Its provocative resistance in public space challenged the state's official and dominant discourse and got it banned. In a nutshell, these adaptations were 'historically contextualized response' to the real events emerging in their time period.

\section{References}

Anwar, T. "Impact of Globalization and Liberalization on Growth, Employment and Poverty". World Institute of Development Economics Research (WIDER) Development Conference, 2002.

Ayaz, Babar. What's wrong with Pakistan? Delhi: Hay House Judia. 2012 Print.

Baker, W. Raymond. Capitalism's Achilles Heel, New Jersey: John Wiley \& Son, 2005

Bashir, Z. "The impact of Reforms and Trade Liberalization on Agricultural Export

Bonaccorsi di Patti, E. and Hardy, D.C. "Financial Sector Liberalization, Bank Privatisation, and Efficiency: Evidence from Pakistan". Journal of Banking \& Finance, Vol.29, No. 8-9,2005.

Brecht, Bertolt. Collected Plays: Three. London: Methuen. 1997. Print.

Eagleton, Terry. Why Marx was right, Yale: Yale University Press. 2011.

Evans-James Roose. Experimental Theatre: From Stanislavsky to Peter Brook. New York: Routeledge, 1970. Print.

Foucault, Michel Discipline and Punish: The Birth of a Prison. Translated by A. Sheridan. New York: Vintage, 1995. Print.

Fuegi, John. "The Zelda Syndrome: Brecht and Elisabeth Hauptmann", The Cambridge Companion to BRECHT, Cambridge: Cambridge University Press, 1994.

Greenblatt, Stephen. Renaissance Self Fashioning: From More To Shakespeare. Chicago: University of Chicago Press, 1980.Print.

Pro forms of Power and the powers of Forms in the Renaissance", Genre 15, 1985.

Gupta, Gautam Sen. "When the windows opened: Communication through foreign adaptations on the Bengali stage". Global Media Journal, University of Calcutta 4/4 (2013).

Hansen, David. 'Radical Rhetoric-Moderate Behaviour: Perceptions of Islam, Shari'a and the Radical Dimensions among inhabitants of Islamabad and Rawalpindi in the post- 9/11 Pakistani Reality', PhD Thesis, Princeton University, 2010.

Hutcheon, Linda. A Theory of Adaptation. New York: Routledge, 2006. Print.

Ingel, Stephen. Socialist Thought in Imaginative Literature. New Jersey: Rowman and Littlefield, 1979.

Khan, Fawzia Afzal. A Critical Stage. Calcutta: Seagull Books, 2005. Print.

Khan, M.A. "Restructuring of Financial Sector in Pakistan." Journal of the Institute of Bankers Pakistan, No 70, 2003.

Khatoon, Salma. "Brecht in Pakistan". Exploration 22(2011)18-30. Print. 
Leach, Robert. Theatre Studies, the basics. London: Routledge, 2008 Print.

Leitch,Thomas. "Adaptation Studies at a Crossroads" Adaptation 1/1 (2008):63-77.

Nadeem Shahid, Selected Play, New York: Oxford University Press, 2008. Print.

-,Preface. Selected Plays by Shahid Nadeem. New York: Oxford University Press, 2008.

Nasr, Vali. The Rise of Islamic Capitalism. Colorado: Kumarian Press, 2009.

Orgel, Stephen, The Illusion of Power: The Political Theatre in the English Renaissance, Berkeley: University of California Press, 1975.

Pritner \& Walter, Introduction to Play Analysis. New York: McGraw- Hill, 2005.

Rahman, Taimur. The class structure of Pakistan. Karachi: Oxford University Press, 2011. Print.

Rahman, Tariq. Language and Politics in Pakistan. Lahore: Sang-e-Meel Publications, 2012 Print.

Raza, Amra "Epic character evolution in Brecht's The Threepenny Opera." Journal of Research (Humanities) xxxiv (2000): 71-87 Print.

Rumi, Raza. "Ajoka - a powerful voice against terrorism and injustice", History of Ajoka Theatre, Lahore: Ajoka Publications, 2011.

Sulieman, Azhar. Studies in Modern Drama: Bertolt Brecht, Mosul: Mena Publisher, 2011.
Shah, S.M.A. "Corporate Debt Policy---Pre- and Post-Financial Market Reforms: The Case of the Textile industry of Pakistan". The Pakistan Development Review, Vol.46,No.4,Part II, 2007.

Siddiqa, Ayesha. Military Inc. Inside Pakistan's Military Economy. London: Pluto Press, 2007.

Siddiqui,Shahid. Language, Gender and Power: The politics of Representation and Hegemony in South Asia, Karachi: Oxford University Press, 2014.Print

Sirajuddin, Shaista Sonnu. Introduction. Selected Plays by Shahid Nadeem. Oxford UP ix-xxv.

Talbot, Ian. Pakistan: A New History. Karachi: Oxford University Press, 2012. Print.

Thomson, Peter. The Cambridge Companion to BRECHT, Cambridge: Cambridge University Press, 2002. Print.

Weiss, Anita M. Culture, Class and development in Pakistan, Lahore: Vanguard, 1991. Print.

Welch, David. The Third Reich: Politics and Propaganda. London: Routledge. 1993.

Project Reports and Brochures

Ajoka Festival Brochure, Musafat. "The Journey continues. Celebrating 25 years of Ajoka Theatre”. Ajoka Theatre, Lahore, 2009.

Ajoka Brecht Theatre Festival Brochure, "25 years of performing Brecht in Pakistan (1985-2010)", Ajoka Theatre, Lahore, 2010. 